\title{
ヒト胆囊粘膜及び胆震コレステローシスの 電子顕微鏡的研究
}

\author{
岡山大学医学部第 I 外科教室（主任：田中早苗教授）
}

高橋 公 雄

〔昭和47年12月25日受稿〕

目次
I. 緒㝘
II. 実験材料及び実験方法
III. 観 察 結果

A. 胆襄粘膜細胞の電子顕微鏡的分類

1. Ordinary epithelial cell
a. 核
b. 細胞膜
c. 細胞質

2. Cear cell

3. Dark cell

4. Basal cell

B. 胆裹コレステローシス

IV. 考 察

V. 結 語

V. 文献

\section{I. 緒言}

胆露について,Virchow"が1857年初めて病理組 織学的所見を発表したが，それ以来生理学的にち形 態学及び生化学的にも多数の研究がなされ，その結 果, 胆襄の重要な機能は吸収と分泌であり, 胆汁よ り水分, 電解質を吸収して胆汁を濃縮するてとが判 明した。

その際, 胆軎の形態学的研究は主に光学顕微鏡に よって行われてきたが，その解像力には限界があり， 微細構造レべルでの発展を望むのが困難となった。

1955年 Yamada ${ }^{21}$ はマウスを使って初めて電子影 微鏡下にその微細構造を報告し，つついてモルモ. 卜 3, 犬”, 羊,'蛙, 魚, 家鬼" の胆尧についても，そ の微細構造の報告が相次き，新しい分野からのアプ ローチか注目を集めた．上卜についても津留”, 田中?" Evett ${ }^{101}$ Bader,1" Heidegger, ${ }^{121}$ 北島 ${ }^{13}$ らの報告か; ある。

しかし, 正常及び病的胆裹粘膜の微細構造, 特に 吸収分䎵機能との関連の詳細は尚不明な点が多い.

一方, Virchow 以来胆衰粘膜細胞光影下に分 類し, 各々の細胞の生理的機能を推論する試みは多
くの伊究者1415161によってなされ，一般に Ordinary epithelial cell, Clear cell, Dark cell, Basal cell の 4 種類に分類されているか， その生 理的意義については議論が多い。需影的には Yamada ${ }^{12}$ 's light barrel-shaped cell $\varepsilon$ dark rodshaped cell の名称を用いて，その微細構造を報告 しそこの機能については前者を変性に宿った細胞, 後者を合成機能が進している細胞とみなした。

今回, 著者は七卜胆管粘膜細胞の電顕的分類を試 み, 各々の微細構造を述べると共に，その生理的機 能及び意義について検討を加えたので報告する。

次に，臨床的に多くはコレステロール結石に合併 して，胆霍コレステローシスにそう遇するてとは展 々あるが, 胆襄コレステローシスにおけるコレステ ロールの由来について吸收説 ${ }^{181}$ と分泌説' ${ }^{19}$ か対立し 未だ決定されていない，著者はコレステローシスの コレステロール顆粒を電顕下に追求し，吸収説を支持 すると思われる所見をえたので合わせて報告する．

\section{II. 実験材料及び実験方法}

1969年 4 月より1971年 3 月まで岡山大学第 1 外科 及び関連病院で胆䨢摘出術をうけた症例のうちから 
胆石症, 胆裹炎, 胆塞ディスキネジー症例50を無作 意に選んだ。胆裏は摘出值後, 胆霍䅡部及ひ底部を 約 $1 \mathrm{~cm}^{2}$ に切除し, 直ちに 4 \%冷グルタールアルデハ イドで30分固定して,つついて $1 \mathrm{~mm}^{2}$ 亿細切して再度 $4 \%$ 冷グルタールアルデ八イドで 2 時間固定した.

次に $\mathrm{pH} 7.4$ の0.2 M燐酸緩衡液にて数回姺保後, 同じ緩衡液の $2 \%$ オスミウム酸で 1 時間固定し，漸 強アルコール系列にて脱水, Epon812に包埋した. thick section はトルイシンブルーで染色洸䫓し, thin section はウラニールアセテート,リードハィ ドロオキサイドにて重固定し,日立 HU-11型電子顕 微鏡で観察した。

\section{四. 観察結果}

\section{A. 胆要粘膜細胞の霆子顕微鏡的分類}

1. Ordinary epithelial cell

胆裹壁の大多数を占めろ細胞は円柱状の Ordinary cell (Fig. 1，6，7，8，9)であろが, 以下 その特辩を記載する。

a. 核

核は微細顆粒状で全体に濃焱の強い斑点状を呈し 辺縁には電子密度の高い圈か存在する，核膜は明瞭 な二重膜構造を示し, 細胞質と明確に分離されてい ろ. 核小体は時々出現し, 電子密度の高い粗大な網 状構造として 1 ～個認められる.

b. 細胞膜

自由表面に microvilli がみられる。（Fig，6，

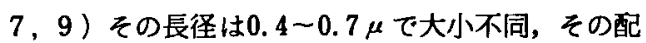
列 も比較的疎であり，方向 も一定していない．てれ は,小晹吸収上皮の microvilli とは著しい差異を呈 する．強拡大では microvilli の表面から垂直に絞 細な樹状突起が観察される。乙れは Yamada antennulae microvillares と名つけたものである. 又 microvilli の内部に, 長軸に一致して細胞質内に 至万電子密度の高い微細な線維の集束像 ( filament bundle ）ちみられる. 自由表面直下あるいは microvilli 間传 pinocytotic vesicle, pinocytotic cell membrane invagination 及ひ caveola intracellularis がみられるとの報告は多いが，著者の 観察では明瞭なものはみられなかった。

次比外側細胞膜が隣接細胞之接する部は内腔側上 り基底部に向って terminal barか存在し, それよ り更に基底部に向って細胞間隙は開大し，複雑な 突起による interdigitation 呈し, 細胞間隙の物 質は均一微細構造である，又細胞間隙の大小は個々
の標本により有意の差を認めるが，病変，年令等に よろ意義つけはできなかった。

$$
\text { c. 細胞質 }
$$

Yamada ${ }^{21}$ は,自由表面から基底部沉向って clear zone, dark zone, supranuclear zone, nuclear zone, basal zone と分類していろ. 細胞内小器官 としてミトコンドリア, ゴルシ䒾置, 粗面小胞体, 空胞状顆粒, free ribosome, lysosome-like-body 等が認められるが，これらは主に dark zone 及び supranuclear zone 亿存在する.

ミトコンドリア：核上部に大多数存在するが，核 下部，基底部にも観察される，明瞭な二重膜に被包 され，円型，楕円型，長秙型を呈する，cristae は 長軸にほほ垂直であるが，枝分れ，蛇行している像 も散見される.多くの場合ミトコンドリアに近接し て周囲を囲む如く粗面小胞体の存在を認め万. 尚, cristae の断裂, matrix の腫脹, 破壊像がみられる こともあるが，乙れは固定中の artifact と考えた い. (Fig. $6,7,8,9$ )

ゴルシ蓀置：ゴルシ装置はゴルシ膜, ゴルシ小胞， ゴルシ空胞から構成されているととは Dalton ${ }^{201} の$

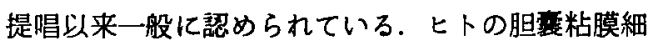
胞においてはほとんどすへてての細胞の核上部に認め られろ.ゴルシ膜は不規則で扁平な内腔を囲む細長 く平行に走る対になった膜よりなり，更にてれらの 3〜4 対か滵比平行して走ろ. その走行中にゴルシ 小胞又はゴルシ空胞を含み，数珠状に観察され，終 末部はゴルシ空胞に終るととが多い，ゴルジ空胞の 内容は極めて明調であるか詳細仁観察すれば微細な 網状構造もみられる. 更にゴルシ装置に近接して後 述する空胞状顆粒が厚々観察されるが,ゴルシ小胞, ゴルシ空胞にはその形態上の特徵から空胞状顆粒の 移行型と思われるものもある.（Fig， 6, 8)

小胞体：小胞体はすへてての細胞にみられろ成分で Palade ${ }^{211}$ の報告に詳しい，細胞の蛋白合成に関与 し，RNA 粒子の有無によって粗面小胞体，滑面小胞 体汇区別する.

著者の観察では多くは自由表面直下から核上部に 至るまで，ミトコンドリアの周囲に粗面小胞体が現 われる. 大きさは0.2〜1 $\mu$ の範囲で細長い小管状， 樽状, 数珠状を呈し, 更に弯曲しながらミトコンド リアをとり囲み，全体として馬蹄型を示すことが多 い，特にミトコンドリアの多い部位では枝分れが複 雑となり,内腔も densityの高い微細顆粒状である. 滑面小胞体はゴルジ膜との識別が屡々困難であり, 
両者の同一性を唱えろ意見もあろ 221 著者の観察では 明確な滑面小胞体は観察できなかった。

( Fig. 6, 7,8)

空盷状顆粒: 空胞状顆粒は電顕下に ring figure, pale droplet" と呼ばれ, 胆雍粘膜細胞に特徵 的である. この顆粒は核上部にのみ限定されて存在 し, 類円型で直径0.5 - 1 $\mu$ 以上に及ぶ. 原則的には 自由表面に近い顆粒程大きさを增し，散在性，又は ブドウ房状に密集してあらわれろ.内容は雲状, 微 細棢状，又は微細顆粒状であろ．ゴルジ装置に近接 して小型の空胞状顆粒が愿々みられ，ゴルジ小胞及 びゴルジ空胞との鑑別困難な移行型も存在する.こ の顆粒は，粘液多糖類の分泌顆粒であろととは一般 に信しられているが, 著者もPAS 染色で確梕し た.（Fig. 2 ）分必様式については，核上部にあ らわれた空胞状顆粒は次第に大きさを增して自由表 面に近づき,内容は雲状から微細顆粒状及至微細網 状構造となり，ついは自由表面の細胞膜と接し， 隔合して内容を管腔に放出する，所謂メロクリン型 分必様式である．尚 microvilli 間及び管腔には放 出された微細網状構造物質が散見される.

次に同一应例について胆衰頚部及び体部で比較検 討した結果, 空胞状顆粒の数, 形態, 性状に有意の 差はなく, 又胆震炎の重症例と軽症例の比較でも， 有意の差を認めなかった，更に胆石によろ影響を調 ヘろへく，有石胆軎炎と無石胆零炎を比較したが， 同様に差を認めなかった.（Fig. 10,11, 12)

Lysosome-like-body：胆稁粘膜上皮細胞の半数 以上に 1 倜及至数個散在性に観察される大顆粒があ ろ. 電顥下で Hayward" が pigment granule, Yamada" が dense body と呼称したものと同一の

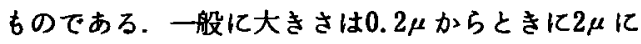
及び，棈円形で周囲の胞体と一層の膜により鮮明に 区別され，浮き上っているかの様に観察されろ.内 部は電子密度が高く均一であろが, 大型のものは濃 谈不でろい小胞が集合した如き像を呈していろ場 合もあろ. 尚ミトコンドリアの破片がての顆粒の周 囲に近接して存在することが時々観察される。この 顆粒は変性細胞や後述する clear cell の変性型に は高い頻度でみられろ。（Fig. 6, 7,8,13)

2. Clear cell

従来,光顯下に周囲の細盷に比へて胞体が明るく， 全体に梅状を呈する細胞があり light cell, cask cell, barrel cell 等と呼ばれていた. ての細胞を 電影下に観察すると，胞体は著しく明調で㭩状を呈
し，胞体成分は柾で一部破壊による空腺もみられ， 細胞内小器官は変性を示している. ミトコンドリア は一般に小さく,円型に臌化し，matrix の density は低く，cristae の断裂像が多い. 又破罗されたる トコンドリアの破片もみられる. lysosome-likebody は高い頻度であらわれるが，その形態，大きさ は変化に富んでいる．又粗面小胞体及びゴルジ装置 の発達は悪く，一方 free ribosome 及び空胞は豊 富である，核はクロマチンに富み，特に辺縁に著し く,核小体のあらわれる頻度は高い（Fig. 13,14)

以上述へた clear cell とは異なり，盷体は明瞭 で clear cell ではあろが，胞体内で核の占めろ割 合が高く, free ribosome 及び filament が豊富で 細胞内小器官の発育が悪く，核はクロマチンに乏し く全体に幼若細胞の特徽を備えた clear cell が存 在すろ.（Fig. 15,16）更に胞体成分は明瞭である が変性像も幼若像もなく, 細胞内小器官の発育も良 好で狭義の clear cell とも呼ぶべき型もあるが， 詳細は尚検討の余地があると思われる.

以上の如く, 従来光影的にも電影的にも $1 \supset の も$ のとされていた clear cell は少なくとも幼若型と 変性型の 2 種類に分類される.

\section{Dark cell}

pencil-like cell, ${ }^{101}$ rod-shaped cell ${ }^{23)}$ との名称 ちあろ. 全体に暗調で細長く周囲から压迫されてい る如き像を示す．横断像では多角形状を呈す．胞体 成分は少なく, 練胞間隙が拡大し, interdigitation は複雑さを増していろ．単独にあらわれろこともあ ろが多くの場合 2 ３個群在してあらわれ，隣接す ろ細胞が clear cell である場合も屡々である. microvilli 及び terminal bar は ordinary cellのそ れと差異はないが，胞体内にゴルシ装置，ミトコン ドリア, 粗面小胞体, その他小胞, 顆粒が密に pack されている. 核はbasal membraneに偏して存在 すろ.

次に場所によろ発見頻度であろが，胆霍䅡部及び 底部に dark cell がみられる頻度は，その差を認め なかった，又 ordinary cell との移行型も存在す 3. ( Fig. 13, 17)

4. Basal cell

全体に類円型で内腔に接することなく，基底膜に 偏してあらわれ，細胞膜は周囲の細胞膜及び基底膜 と複雑な interdigitation を示す.一般に胞体成分 は疎でミトコンドリア及び粗面小胞体は少なく， ゴルジ装置をみるととはほとんどないが, 稀に粗面 
小胞体か発達したもの, ミトコンドリアの豊富なも の, 顆粒の充満した basal cell を慧める. 核は不 正形で展々陥凹を認め，クロマチンに富み，核小体 を有しない，同様の細胞は胃，小渴，気管にもみら 九る. (Fig. 18)

B. 胆婁コレステローシス

胆典コレステローシスは病理組織学的に泡沫細胞 の出現か特徽である." この泡沫細胞は粘膜細胞直下 の粘膜固有屇に集団となり，互いに密に接してあら われる，個々の泡沫細胞は略円型で大きさは15及至 $20 \mu$ 亿及゙. 泡体は明調な顆粒で充渾され，泡状に 観察され,核は辺縁に偏在する。（Fig. 5) 典型的 な場合は泡沫細胞は密集していろが，一部の粘膜固 有屬では泡沫細胞は散在する. 又密集する泡沫細胞 群の周辺では, 泡沫細胞の前段階とるいうべき, 胞 体内に顆粒が密でない細胞もみられる，泡沫細胞内 に多くのコレステロールが含まれているてとは，既 に明らかであり 25!明調な顆粒がコレステロールであ ろことは一般浲められている. 著者は Sudan black 染色で脂質であるてとを確認した.（Fig. 4)

次に胆辜コレステローシスにおける粘膜細胞及び 粘膜固有層の微細構造を報告する。

粘膜細胞の mic rovilli は,コレステローシスのな い場合と比へ,特に発達が著しいということはなく， 更に pinocytotic vesicle, 及び pinocytotic granule 認めなかった。

核上部には直径 50 及至 $500 \mathrm{~m} \mu$ で大小不同, 不定形 呈し,内容は電子密度が低く,班点状, 破片状, 無構 造状と多彩な样相を示す顆粒が散在する. ( Fig. 19, 20)てれは明らかに空胞状顆粒とは異なり,コレステ ローシスの場合, 著しく增加している. Imaeda $a^{26)} k$ よれば飽和脂肪酸は Os に反応せず, electron density は低い, 即ち電顕下で clear vacuole として 認めると述へており，この顆粒はコレステロール顆 粒と思われる。

核下部は核上部と比べ形態が異なり，核直下，核 に接して20及至80個のコレステロール顆粒が蜂の果 状, 袋状に密集してあらわれる，(Fig. 3,21）個

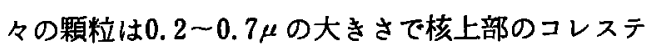
ロール顆粒に比へて円形に近くなり, 又内容も明調 さを增し, lucent vacuole の形態をとる. 隣接顆 粒膜は不鮮明で厚く，互いに入りくみ偽足をだして いる像も観察される. 光䫓下, トルイシンブルー染 色でも核下部に蜂の巣状, 袋状に集結したコレステ ロール顆粒は明膫に観察されろ（Fig. 3) この
様な粘膜細胞は10２0個連続して集団をなしている が，乙の部の粘膜固有屇には泡沫細胞は存在せず, コレステロール顆粒を含んだ網内系細胞か潵在する のみである.

一方, 粘膜固有屇汇泡沫細胞少密集する部の粘膜 細胞にはコレステロール顆粒は少ない（Fig. 5)

隣接細胞間は, tight junctionでは密に閉鎖して いるが，それより基底部側では細胞間隙は挔大し， interdigitationは複雑となり，時に数珠状にみえる 場合もある.（Fig. 22）尚著者はての部の Sudan black 染色を行い，陽性であることを確認した。

つついて基底部ではコレステロール顆粒の集団は 蜂の笨状構造が湖れて散在性に基底膜に近づく. 顆 粒は大小不同で核下部のコレステロール顆粒に比へ 更に一粕円非に近く，内容も lucentである．基底 膜に接した顆粒の集团が基底膜を粘膜固有層側へ〔E 迫している像は観繁できろが，基底膜を通過する状 態の顆粒は観察できなかった．細胞間隙は基底膜に 近つくと更に拡大し, interdigitationも一段と複雑 さを增してくろが，基底膜に接する部は閉鎖してい 了.

基底膜は unit membrane 構造 ${ }^{2 n}$ で，コレステロ ーシスの場合に特徽的所見はないが，基成膜馗下に 膠原線維の出現が著明で，特にその横断像は特有な 星芒状で，電影的にコレステローシスを特徽つけて いる. (Fig. 23, 24)

粘膜固有畨には網内皮系細胞が多くあらわれ，喠 々な段階をへて泡沫細胞に至る. 光顕下でる密集し た泡沫細胞の周辺にはコレステロール顆粒を取込ん だ末完成の泡沫細胞が観察できろが，電顕下では粘 膜細胞から移行したコレステロール顆粒は基底膜淔 下の網内皮系細胞の胞体中にあらわれる. その網内 皮系細胞の構造は, 胞体の大部分を占めろ dense body の存在か特徽である. ての dense body は0.8 及至1. $2 \mu$ の大きさで, 内部は大小不同の明調な小胞 が数個集合したものである. 更に, small lucent vacuole, myelin figure, 針状結晶むみられ, 多彩 な様相を呈する．次の段階において網内皮系細胞に は large lucent vacuoleがあらわれ, dense bo$\mathrm{dy}$, myelin figure, small lucent vacuoleは少 なくなり,つついてその率が逆転し，ついには網内 皮系細胞中に lucent vacuole か㳘满する, 即ち泡 沫細胞となる. との過程で, small lucent vacuole はコレステロール顆粒であり, dense body は small lucent vacuole が集合したものであり, large 
lucent vacuole は small lucent vacuole $か$ 溌育 したものであるという印象を受けた（Fig. 25）

泡洙細胞は胞体全体に large lucent vacuole が 充満し，顆粒は互いに偽足をだして隔合する像もあ ク, 又一部は lucent vacuole の形態をとらず，辺 縁の内容か網状を呈していろものちあろか;, 全体か ら観察すれは，粘膜細胞内のコレステロール顆粒と ほとんど同一のものであろ，泡沫細胞の核は顆粒に 压迫された如く周辺に存在し，細胞内基質にそしく， ミトコンドリア，粗面小胞体及びゴルシ装置は殆ん ど見い出しえない（Fig. 26）

\section{IV. 考察}

Ordinary epithelial cell について

ヒトの胆霍粘膜の微細構造は, マウズ', モルモッ

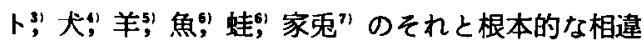
点はない.

microvilli の機能については，一般に吸収の際表 面皘を拡大する為に存在すると信じられているが， 胆整の microvilli は小腸に比へ疎であり，胆素が分 子量の少ない水, 電解質, コレステロール等を吸収 すろ祭, microvilli が関与していろかどうか不明で あろ. 更に， pinocytosis が吸収の主機構であり， pinocy totic vesicle の存在を唱える説(3) が大部分 をらめろが，著者の観察では明瞭なものは認めなか った．本来,自由表面には複雑な invagination があ $\eta$, 又 microvilli の蛇行, 交叉か沏断方向によって 小胞状にみえたり, 更に小型の空胞状顆粒や artifact も存在する. これら任ocytotic vesicle と みなす可能性は強い，以上のてとから小腸吸収上皮 の pinocytosis と異なり，胆整におけろ水分，電解 賈の吸収は浸潤, 拡散, 電位差等の物理現象で行わ れると考える方が安当であり, pinocytotic vesicle が存在することは疑問である.

ヒト胆震粘膜細胞に特有な空胞状顆粒について, その微細構造及びメロクリン型分泌様式は他動物に おけろ多くの報告と一致し, 内部の雲状及至網状構 造が特徵であり，性状についてはPAS陽性の粘液 多糖類で組織化学的検索 ${ }^{15)}$ と一致する. 生成場所に ついてはゴル装置に起因することは一般に信しら れており, 著者の観察でもゴルシ小胞, ゴルジ空胞 との移行型を思わせる空胞状顆粒が存在し, 逆に空 胞状顆粒に近接してゴルシ装置があるととは多い. しかしゴルジ胞が発達して空胞状顆粒となるか, ゴルジ空胞が何らかの機序で集合し空胞状構造にな
ろか不明である．意義については北島 ${ }^{131}$ が病的条件 下にこの顆粒か増えるととにより，炎症産物と推定 していろが，著者の観察では既述の如く，炎症の程 度により差異を認めなかったので，炎症産物とは考 えにくい，一方，Womack ${ }^{23)}$ の提唱以来胆石の生因 に重要な役割りを演し，胆砂を集合させる接着剤様 作用を有するとの説は多く，槙等 ${ }^{29}$ は特殊な組織化 学的検索によって胆石内に酸性粘腹物質の架橋構造 を認めろことから, 空胞状顆粒の胆石生因に対する 役割りを述へていろが，著者の観察では無石胆衰炎 にも空胞状顆粒は存在し，その形態，数も差異はな い. 胆石生成の際，自由表面に分泌された粘液多糖 類がまきてまれ，それが架橋状に観察される可能性 もあり, 空胞状顆粒か胆石生成の主役とは考えにく い. 中村 ${ }^{30}$ は家鬼に Dehydrocholesterol を投与し て胆石の生成をみ，その後で空胞状顆粒の出現をみ たとして, 空胞状顆粒は粘膜上皮に粘性を与え，結 石によろ機械的刺激を防俸抑制すると考えた，著者 は無石胆婁炎にも空胞状顆粒を認めたので，胃にお ける mucous droplets $の$ 如く, 単に mucous barierが空胞状顆粒の意義であると推論するちので ある.

lysosome-like-body は Aschoff" が吸収された 胆汁色素, 即 5 phagosome と呼称し, Nagahiro's1 が特殊リポイド顆粒と記載したものと同一のものと 思われろ. 電顕下には Hayward" が pigment granule, Yamada's しているものと一致する. lysosome の機能につい $て$ Novikoff ${ }^{2)}$ は細胞質の部分的自己消化機能を指 摘したが，著者は lysosome-like-body の意義につ いて, clear cell の変性型や変性細胞に高い頻度 であらわれ，又ミトコンドリア debris や free ribosome の破片集合物を思わせる像があり，細胞の 機能変化に伴って不用となった既存の細胞内小器官 の生理的自力排除のために現われたと考えられる. 尚, 名称について de Duve ${ }^{33)}$ が生化学的 approach にて肝細胞中に lysosome を発見して以来, lysosome は加水分解䣼素を含み，一層の限界膜を有する 顆粒と定義されたが，形態学的には Novikoff ${ }^{321}$ が, その多様性を指摘し, 名称は混乱した，近年 primary lysosome, secondary lysosome の概念加提 唱され, 整理されつつあるが，著者は酶素活性を測 定していないので純形龍学的に lysosome-like-bodyという名称を採った. 
胆雴粘膜細胞の電顕的分類について 胆衰粘膜細胞の分類は Pfühl' が光顕下に light barrel-shaped cell $と$ dark rod-shaped cell $\sigma$ 存在を粮告して以来, ordinary cell を含めて 3 種 類に分類された，尚，Pfuhl は light cell を水分， 電解質を吸収した細胞, dark cell を機能减退を示 す細胞と推則している，つづいて basal cell を含 めて 4 種類に分類され，一般に信じられるに至った が, その各々の意義について諸説があり, 決定され

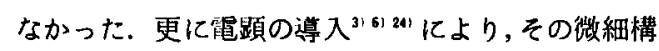
造上の特徽は light cell（以下 clear cell）には lysosome-like-body が紀富であり, dark cell に はゴルジ装置が多いとされている. clear cellの意 義について大別すれば, Yamada ${ }^{241}$ のいう declining activity と Hayward ${ }^{31}$ のいう細胞内吸収機能立進, 即ち hydration という2つの意見がある.との意見 の対立は頻慗にみられろ dense body ( lysosomelike-body）についての考え方の相違による. 即ち Yamada は dense body をそトコンドリア debris の集合した変性顆粒と主張し，Haywardは吸収機 能進の為增加した pinocytotic vesicle が集合し たものと推祭していろ. 著者の钼祭では lysosomelike-body は前述した如く, 自己消化機能座物であ $\eta$, clear cell は細胞頃, 核の形態加らも degeneration type と推測したい. 一方, 胞体の電子密度 か低く, clear cell ではあるが, 内部構造は幼若 細胞の特徴を備えており, 変性像の全くないclear cell る存在する. 著者はこの細胞を clear cellの immatured type と命名した. 光䫓レベルではdegeneration type と immatured typeの鑑別は困難 であり, 電顕レベルでは immatured type の clear cellについて全く記載がない. 更に clear cellで はあるが, 変性像も幼若像もない型吉観察される. この様な clear cellの多様性が，その意義につい て種々な意見の対立を生む一因ではなからうか.

dark cell の意義については光顕下に, Goblet cell に由来するもの3'機能停止とした静止細胞,“変性 練胞;5) ordinary cell との移行型,'等種々な意見が ある. 電顕下には Porter ${ }^{\mathbf{3} 6}$ が蛋白合成細胞, Hayward $^{3 \mid}$ か ordinary cell $の$ dehydration type, Bader ${ }^{61}$ が未分化細胞汃ら ordinary cell 人の移行 型と推定した．田中"1 は脱落する可能性はあっても 変性に宿っている証拠はないと述へている. 一方, Yamada"1 はゴルシ装置, 粗面小胞体, free ribosome が多いととから合成機能六進型と考え, ミト
コンドリアが多いのはエネルギーの供与の為, muItivesicular body, multigranular body の出現は その結果と考えた。著者の観察でも，ミトコンドリ ア,ゴルシ装置, 粗面小胞体, free ribosomeは多 いが, 合成機能の亢進を示すか, dehydration type 加決定し難い, dark cell は2 - 3圈集まって現わ れることが多いてとや，細胞間隙が大で interdig-

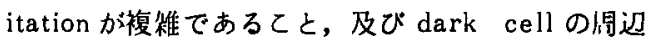
には clear cell (degeneration type) がよくみ られるととは, dark cell が dehydration type で あることを示唆している様にも舁える. Yamada" はこの意兒の対㲸についで完験動物の種類や artifactによるものと考元ている，薯者は㙨能元進，又 は脱水による機能沿退，いずれにしろ ordinary cell との移行型の存在, 上記細胞内小器官が少ない dark cell も存任するととから, dark cellは ordinary cell と移行する細胞と橴えている.

basal cell は気管，胃，小腸にもみられる，Rh$\operatorname{odin}^{361}$ は気管粘膜内の basal cell をリンパ球とみ なし Palay ${ }^{3 n}$ は小腸吸収上皮の basal cell t macrophage とみなした。蓄者は冒粘膜の basal cell を観祭した結果，胆哂のbasal cell と同一のもの とみなし,リンパ球にその微細棈造が類似している 印象をうけた。意義については，その起源がリンパ 球か macrophage かという問題に要約できる。

胆軎コレステローシスについて

コレステローシスの組織学的特徽は泡沫細胞であ ろ. 泡沫細胞の起源に関してリンパ管内皮由来, 血 管内皮由来, 結合織由来, 未分化間葉細胞由来, 食 細胞由来等多くの学説が唱えられたが, 細網内皮系 統の概念が確立されて以来, 泡沫細胞の起源を本系 統に求めろ数多くの基礎的研究が行われ，泡沫細胞 が網内皮系細胞に由来するととは, 今日一般に信し られるに至った。

さて泡沐細胞にとりこまれるコレステロールの由 来について，大別すれば Aschoff(1) による胆汁より 吸収されたコレステロールが何らかの吸収機構の久 陥により血中に移行せず，胆整壁に蓄積すると考え ろ吸収説と胆震壁で合伐されると考える Naunyn ${ }^{191}$ やMentzer ${ }^{38)}$ の説が対立し，今日吸収説が一般に信 じられているが, 企身黄色腫症の概念より胆茠コレ ステローシスを一分症と考えると, 高コレステロー ル血症による血中からの脂筫摂取機序によるコレス テロールの蓄積39! 又は網内皮系細胞のコレステロー ル合成説 ${ }^{381}$ も根強い，吸収説をとる Bagnoli“10) らは 
吸収機棈の欠陷を胆婁壁のリンパ系のうっ滞に求め ている.

一方, 組織化学の立場より血中のコレステロール はエステル型であり，胆汁中のコレステロールは遊 離型であるととは一般に信じられている。勝野は11は コレステローシスの胆襄壁より抽出したコレステロ ールが大部分エステル型であることから、コレステ ローシスの生因を血中コレステロールの蓄積と推論 していろ.川島は2はコレステローシス胆隻壁のコレ ステロール組成について,エステル型と遊離型が 1

：1 の割合で存在するとみなし, 胆笙粘膜細胞内に 非特異性エステラーゼを証明して，エステル型が存 在する理由を明らかにし，吸収説を支持している。

著者は既述の如く，コレステロール顆粒を粘膜細胞 から固有層の泡沫細胞まで観察し，吸収説を支持す ろものであろ.

胆汁よりコレステロールが粘膜細胞へ吸収される 機構は pinocytosis とは考えにくく，コレステロー ルの分子量 (170) を考虑すれば水, 電解質と同様に, 浸閏, 拡散, 電位差等の物理現象によって粘膜内に とりこまれると推論する、粘膜細胞の核下部にコレ ステロール顆粒が集結する機序については全く不明 である. 基底部より固有首への移行は沜態学的に把 握することはできないが, 自由表面の場合と同様に 浸潤，昖散，電位差等によるものと考えられる。梶 原ら ${ }^{31}$ は細胞間腺からのみ固有層へ移行すると述へ ているか，著者の観察では明らかに胞体からの移行 もあり，むしろその方が主体であると思われろ．基 底膜直下の固有層に膠原線維が多くみられることは 川島“21 も報告しているが，その意義は不明である.

粘膜固有層に移行したコレステロールは網内皮系 細胞にとりこまれるが,この機序について價食, pinocytosis, transformation, 浸潤等の諸説が提示 されているが，一般には飡食作用によって捸取され ろという考えが支配的である. 尚, I meada ${ }^{26}$ は泡 沫細胞内に pinocytotic lipid droplet を観察し, pinocy tos is を脂質摄取機序とみなしている. 最近 の知見では phagocytosis と pinocytosisは原則的 には同一の機転であるととが判明し，両者を合わせ て食作用 (cytosis) と㭔んでいる.泡沫細胞の前 段階ともいうへき網内皮系細胞の胞体中には dense body, myelin figureがみられろ.

コレステロール顆粒を電䫓下に観察した場合, Henry;' Imaedas’ Wigglesworth ${ }^{451}$ によれば不飽和脂 肪酸は osmiumに強い反心を示し, electron dense
として観察され，飽和脂肪酸はOs 反応性を欠き， clear vacuole として観察される.との説に従えば 粘膜細胞内のコレステロール顆粒はその組成上, 遊 離コレステロールと飽和脂肪酸とのエステル型コレ ステロールが大部分を占める. 又網内皮系緗胞にと りとまれたコレステロール顆粒即ち, dense body は不飽和脂肪酸とのエステル型コレステロールが大 部分をしめ, dense body 中の明調な部分及び small lucent vacuoleは飽和脂肪酸のエステル型コ レステロールと思われろ. 远に泡沫細胞への移行の 段階で large lucent vacuole が大部分をしめてく ろが,これは何らかの機序で不館和脂肪酸エステル か解除され，遊㰚型コレステロールとなると思われ 3.

以上は推論の段倩であり, 粘膜細胞中の遊離型, 飽和脂肪酸エステル型コレステロールが網内波系細 胞にとりこまれろ際, 何故不飽和脂肪㕹エステル型 の形態をとるか問題があり, 網内皮系細胞内にエス テラーゼを証明したという説もあるが，いずれにし ろ今後の研坌を待たねばならない.

myelin figureは特有な onion-like-figure とし て倠祭され, Trubowitz ${ }^{461}$ は燐脂的類似の有機燐酸 化合物が同様の機造を示すととからレシチン等の燐 脂供の存在に华接な圆係があると推測している。

它成した泡沫細胞は胞体内に large lucent vacuole が先満し, 細胞内基啠に汒しく，ミトコンド リアが殆んど見いだされないととから，本細胞の機 能诚退を推測しうると考えられる.

\section{V. 結語}

ヒト胆堡粘膜及び胆䨢コレステローシスを光頻下,

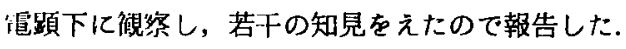

1）上トの胆䨢粘膜細胞の微細構造は他動物のそ れと根本的相違はない.

2）胆整粘膜の吸収機構は pinocytosis とは考え にくく，浸潤，拡散，電位差等の物理現象によるも のと推定される.

3）穵胞状顆粒はPAS 陽性の分泌顆粒で，メ口 クリン型の分泌様式であり, 意義は mucous barierであると思われる.

4）lysosome-like-bodyは自己消化機能の産物 であり変性顆粒と推定される.

5）従来, 光顥下及び電顕下に1つのものとして 述べられていた clear cellは少くとも変性型と幼 若型の 2 つに分類できる. 
6) dark cell は ordinary cell と移行し, ordinary cell の脱水型である印象を受けた.

7）胆裹コレステローシスの生因は胆汁よりコレ ステロールが粘膜細胞に吸収され，基底膜を通って 粘膜固有層に移行し，網内皮系細胞にとりこまれて 泡沫細胞になると考元，吸収説を支持する．

8）コレステロール顆粒は粘膜細胞内及び泡沫細 胞内では遊離コレステロール, 又は飽和脂肪酸エス テル型コレステロールが主体であり，泡沫細胞の前

VI. 文

1) Virchow, R. : Über das Epithel der Gall enblase und über einen intermediären Stoffwechsel des Fettes. Virchow Arch. Path., 11, 574, 1857.

2 ) Yamada, E. : The fine structure of the gall bladder epithelium of the mouse. J. biophys. biochem. Cytol., 1, 445, 1955.

3) Hayward, A. F. : Electron microscopic observations on absorption in the epithelium of the guinea pig gall bladder. Z. Zellforsch. microsk. Anat., 56, 197, 1962.

4 Johnson, F. R., McMinn, R. M. H. \& Birchenough, R.F. : The fine structure of the gall bladder epithelium of the dog. J. Anat., 96, 447, 1962.

5 ) Hayward, A. F. : The fine structure of the gallbladder epithelium of the sheep. $Z$. Zellforsch. microsk. Anat., 65, 331, 1965.

6) Bader, G. : Die submikroskopische Struktur des Gallenblasenepithels und seine Regeneration I. Mitt., Z. mikr. anat. Forsch., 74, 92, 1965.

7) Hayward, A. F. : An electron microscopic study of developing gall bladder epithelium in the rabbit. J. Anat. (Lond.), 100, $245,1966$.

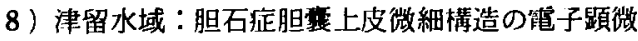
鏡的研究.久留米际学会雑誌，22，4122，1959.

9 ) 田中和雄: 胆石症に於ける胆裹上皮の電子顕微 鏡的研究. 日消会誌，61，537，1964.

10) Evett, R.D., J.A.Higgins, and A. L. Brown : The fine structure of normal mucosa in human gall badder. Gastroenterology, 47,
段階の網内皮系細胞内では不飽和脂肪酸エステル型 コレステロールが主体であると思われるが，詳細は 尚今後の研究を待たねばならない。

（稿を終るに臨み，御指導，御校閲を睗った田中早 苗教授に謝意を表わすと共に，本実駼汇亘接御指導 を載いた緒方卓郎講師に深謝いたします.)

本論文の要旨は，第 3 回日本臨床電子顕微鏡学会 において発表した。

献

49, 1964.

11) Bader, G. : Die submikroskopische Struktur des Gallenblasenepithels III. Mitt., Frankfurt Z. Path., 74, 502, 1965.

12) G. Wolf-Heidegger, W. Styubli und Hess : Zur Ultrastruktur und Histochemie der Gallenblasenschleimhaut des Menschen und der Katze. Acta anat., 62, 606, 1965.

13）北島正是：胆蓑粘膜の微細構造に関する研究. 日消会誌，65，589，1968。

14) Pfühl, W. : Die Gallenblase. Möllendroffs Handb. d. mikr. Anat. d. Menschen. Berlin, Julius Spriger, 5, 428, 1932.

15) Nagahiro, K. : Zytologische Untersuchungen über die Epithelzellen der Gallenblase des Menschen. Cytologia, 9, 132, 1938.

16) C. Togari and T. Okada : The fine structure of the Epithelium of the human Gallbladder. Folia. Anat. J ap., 25, 1, 1953.

17) Yamada, K. : Some observation on the fine structure of light and dark cells in the gallbladder epithelium of the mouse. Z. Zellforsch., 84, 463, 1968.

18) Aschoff, L. : Bemerkungen zur pathologischen Anatomie der Cholelithias is und $\mathrm{Ch}$ olecystitis. Verh. Dtsch. path. Ges.,

9, 41, 1905.

19) Naunyn, B. : Die Gallenstein, ihre Entstehung und ihr Bau. Mitt. Grenzged. Med. Chir., 33, 1, 1921.

20) Dalton, A. J., and Felix : Cytologic and cytochemical characteristies of the Golgi substance of epithelial cells of the epid- 
idymis In Situ, Inhomogeates and after isolation. Am. J. Anat., 94, 171, 1954.

21) Palade, G. E. : A small particulate component of the cytoplasm. J. Biophys. Biochem. Cytol., 1, 59, 1955.

22）山田英智：細胞の微細構造について. 福岡医誌, 47. 1292, 1956.

23) Yamada, K. : Chemocytological observations on two peculiar epithelial cell types in the gall bladders of laboratory rodents. Z. Zellforsch., 56, 180, 1962.

24) Touton, K., Arch. f. Derm. u. Syph., 12, 3，1885. (文献39より引用)

25) Cook, R. P., Kliman, A. and Fieser, L. F. : The absorption and metabolism of cholesterol and its main comparisons in the rabbit with observation on the atherogenic nature of the sterols. Arch. Biochem. Biophys., 52, 1439, 1954.

26) Imaeda, T. : Electron microscopic study of xanthoma cells. The J. of Investigative Dermatology, 34, 331, 1960.

27) Robertson, J. D. : The cell membrane concept. Proc. Physiol. Soc., 140, 58, 1957.

28) Womack, N. A., Zeppa, R., and Irvin, G. L. III : The anatomy of gallstones. Ann. Surg., 157, 670, 1953.

29）槙哲夫：会長講演（回虫から胆石そして石灭化 人). 日本外科学会雑誌，71，1591，1970.

30）中村善啓：胆石倠成に関す万実験的研究，洰学 研究, 31，1361， 1961.

31) Aschoff, L. und Baemeister, A. : Die cholelithiasis. Jena Qusta Fischer, 1909. (文

32) Novikoff, A. B. : Lysosome and related particles, The Cell, 2, New York and London, Academic press, 136, 1959.

33) de Duve, C. : The lysosomes concept. Ci献16より引用)

ba Found. Symp. Lysosomes, 1, 1963.

34) Shikinami, J. : Beiträge zur mikroskopischen Anatomie der Gallenblase. Anat. Hefte., 36, 1908.

35) Mori, Sh. : His tology and histogenes is of the gallbladder. Nagoya Igakkai Zasshi, 47, 1938.

36) Rhodin, J., and Dalhamn, T. :Electron microscopy of the tracheal ciliated mucosa in rat. Z. Zellforsch. mikr. Anat., 44, 345, 1956.

37) Palay, S. L., and Karlin, L. J. : An electron microscopic study of the intestinal villus. J. Cell Biol., 17, 375, 1963.

38) Mentzer, S. H. : Cholesterosis of the gallbladder. Am. J. Path. 1, 383, 1925.

39）小島瑞：黄色腫の概念, 最新炈学，21，522, 812, 1966.

40) Bagnoli, S. \& Monaci, M. : Le alterationi venose, distrofiche e del riassorbimento dei lipidi nella parete della cistifellea in corso di cirrosi epatic a. Arch. De Vecchi Anat. Pat. 18, 455, 1952.

41）勝野馥：胆重粘膜の脂听情成，特に絣様胆霆粘 膜斑点沈着脂赑の由来. 炬学研究, 37, 609, 1967.

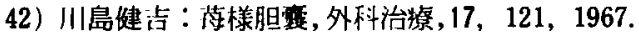

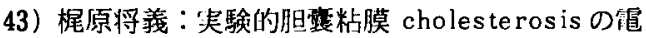

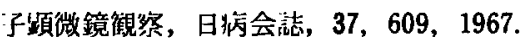

44) Henry, C., McGill, Jr. and Jack, C. Geer : The human Lesion. Fine structure, $65,1963$.

45) Wigglesworth, V. B. : The use of osmium in the fixation and staining of tissues. Proc. Royal Soc. London, 147, 185, 1957.

46) Trubowitz, S., J. Invest. Derm., 34, 177, 1960. （文献39より引用）

附図説明

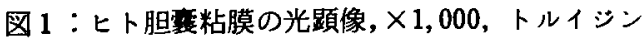

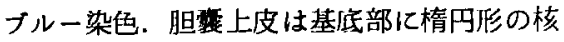
が偏在する一層の円柱状粘膜細胞よりなる。
図 2 : ヒト胆軎の光顕像, $\times 1,000$, PAS 染出. 核上部の顆粒は PAS 陽性即ち粘液多糖類で あることを示している. 
図 3 : 胆毫コレステローシスの光顕像, $\times 1,500$ ，卜 ルイシンブルー染色. 粘膜細胞の核直下より 基底部にかけてコレステロール顆粒が袋状に 充满している.

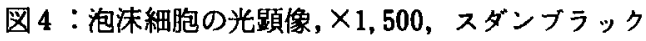
染色. 泡沫細胞内の明調な顆粒はスダンブラ ック陽性即ち脂質であるととを示している。

図 5 : 泡沫細胞の光影像, $\times 1,500$, トルイシンンフル 一染色. 泡沫細胞は略円型で，胞体は明調な コレステロール顆粒で充満され，核は偏在す ろ.

図 6 ：Ordinary cell の電顕像, $\times 5,000$. 自由表面 にマイクロビライがみられ，胞体内にミトコ ンドリア. ゴルジ装置. 小胞体. 空胞状顆粒, lysosome-like-body 等の細胞内小器官か観 察される.

図 7 : lysosome-like-body $の$ 電顕像, $\times 5,000$. lysosome-like - body は㗳焱不ぞろいで大小 不同の小顆粒が集合した如き像を呈し，一㬝 の膜によって咆体と鮮明に区別される. (矢印)

図 $8:$ 図 7 の強拡像, $\times 15,000$.

図 9 : 自由表面の強拡像, $\times 15,000$. マイクロビラ イは長短不同で方向 も一定しない. 又 filament bundle $p$ antennulae microvillares $\phi ;$ 観察される.

図10：空胞状顆粒の電影像, $\times 5,000$ ，類円型で内容 は特徵的な雲状, 微細網状, 微細顆粒状であ 3. (矢印)

図 11 : 空胞状顆粒の電影像, $\times 10,000$. 空胞状顆粒 は自由表面の細胞膜と接し，分歩する直前の 状態を示す（矢印）

図12：空胞状顆粒の電影像， $\times 20,000$. 空胞状顆粒 はメロクリン型分必椂式にて, 内容を管腔に 故出する. (矢印)

図13，14：Clear cell (変性型)の電顕像, $\times 5,000$. 胞体成分は疎で，一部空隙 も みられ，細胞内 小器官は変性像を呈する。
図15，16：Clear cell（幼若型）の電顕像, $\times 5,000$. 胞体内ic free ribosome, filment $力$ 澧富 で細胞内小器官の発育か悪い。

図17：Dark cell の電䫓像, $\times 5,000$. 胞体成分は少 なく暗調で，細胞問陌は拡大し，胞体内に細 胞内小器官嘧に存在する.

図18：Basal cell の電顕像， $\times 5,000$. 基底膜（矢 印）に接して発現し，胞体成分は少なく，核 はクロマチンに富み，核小体を有しない，

図19：胆裹コレステローシスの電影像, $\times 5,000$. 核 上部，自由表面下に斑点状，破片状，無構造 状と多彩な様相を呈するコレステロール顆粒 が存在する。

図20：図19の強拡像， メ15,000. 矢印はコレステロ 一ル顆粒を示す。

図21：胆哓コレステローシスの電顕像， $\times 10,000$. 核下部に明調なコレステロール顆粒か擞10個 袋状㑻集してあらわれる.

図22：胆震コレステローシスの電顕像, $\times 5,000$. 細 胞間隙は拡大し, interdigitationは複雑さを 增す.コレステロールを含んだ細胞間隙の内 容は時に数珠状にみえる場合るある.（矢印）

図23：胆蓑コレステローシスの電影像， $\times 10,000$. 基底部に移行したコレステロール顆粒は内容 が一段と明調になり，型も円型に近つく．矢 印は膠原線維である。

図24：胆唄コレステローシスの電顕像, $\times 5,000$. 粘 膜固有層の網内皮系細胞にとりとまれたコレ ステロール顆粒.（矢印）

図25：図24の強拉像，×10,000、コレステロール顆 粒を哴食した網内皮系細胞か泡沫細胞人移行 する像で，コレステロール顆粒は明調及び暗 調で，形態も異なり，種々な樣相を呈する. 矢印は myelin figure t示す.

図26：泡沫紐胞の電顕像， $\times 10,000$. 胞体全体に大 きな明調顆粒（コレステロール顆粒）が充満 している. 


\section{The Fine Structure of Human Normal \\ Gall Bladder and Cholesterosis}

by

\section{Kimio TAKAHASHI}

Department of Surgery (Prof. S. Tanaka),

Okayama University Medical School, Okayama

Human gall bladders specimens obtained soon after cholecystectomy from $\mathbf{5 0}$ patients were observed under electron microscopy.

Four types of cells were distinguished by light and electron microscopy in the human gall bladder epithelium, i. e.," Ordinary epithelial cell"," Clear cell"," Dark cell", and" Basal cell". The Clear cell have been subdivided at least two types by electron microscopy.

One was degenerative type and another was immatured one. It was also observed that the mechanism of discharge of secretory granules was the" Merocrine mode".

In the cholesterosis, it was assemed that cholesterol was absorbed into the epithelial cells from the bile and accumlated in their basal area, then discharged through their basis.

It was taken by phagocytes which gradually transformed into the foamy cells. 


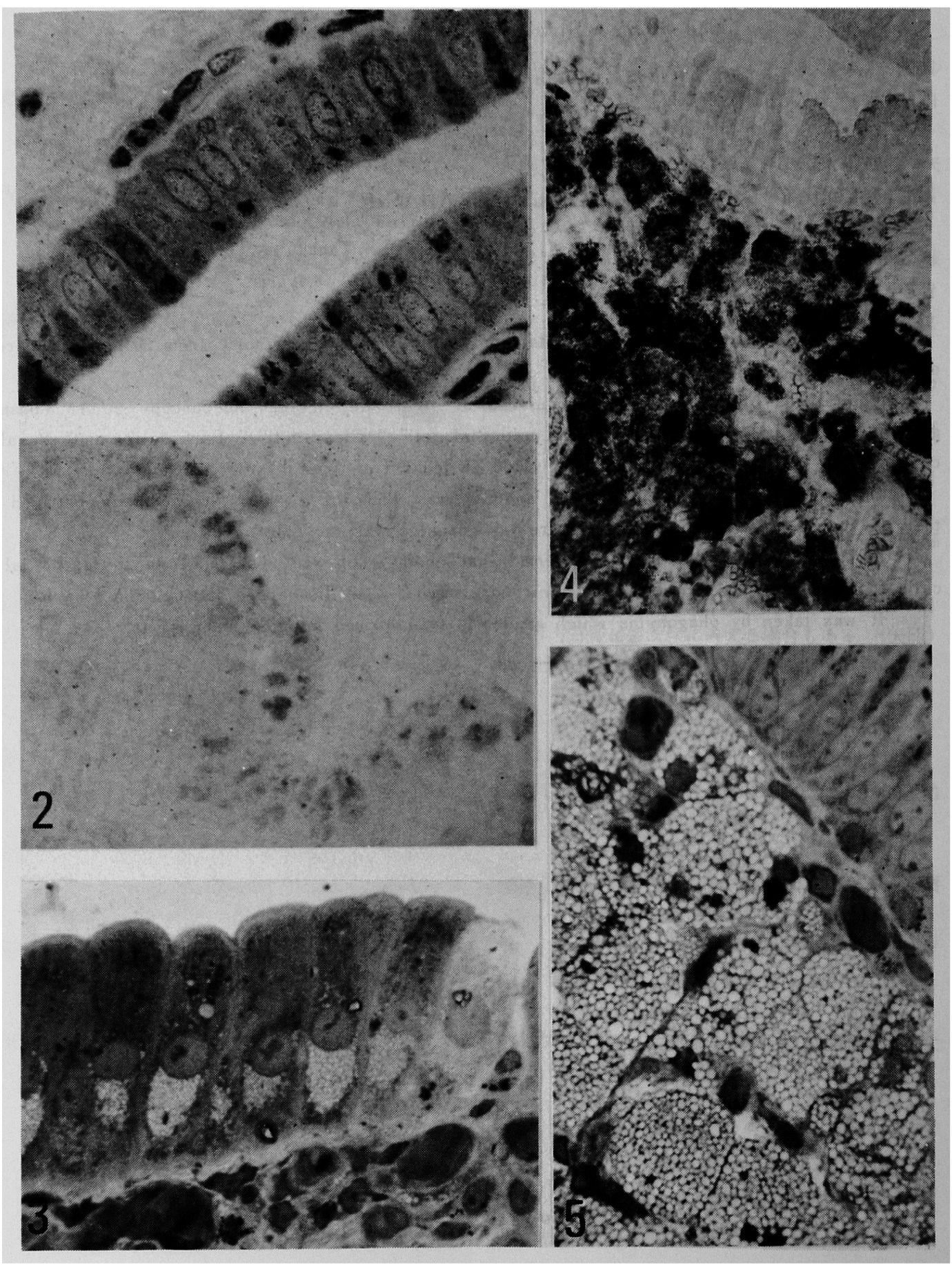




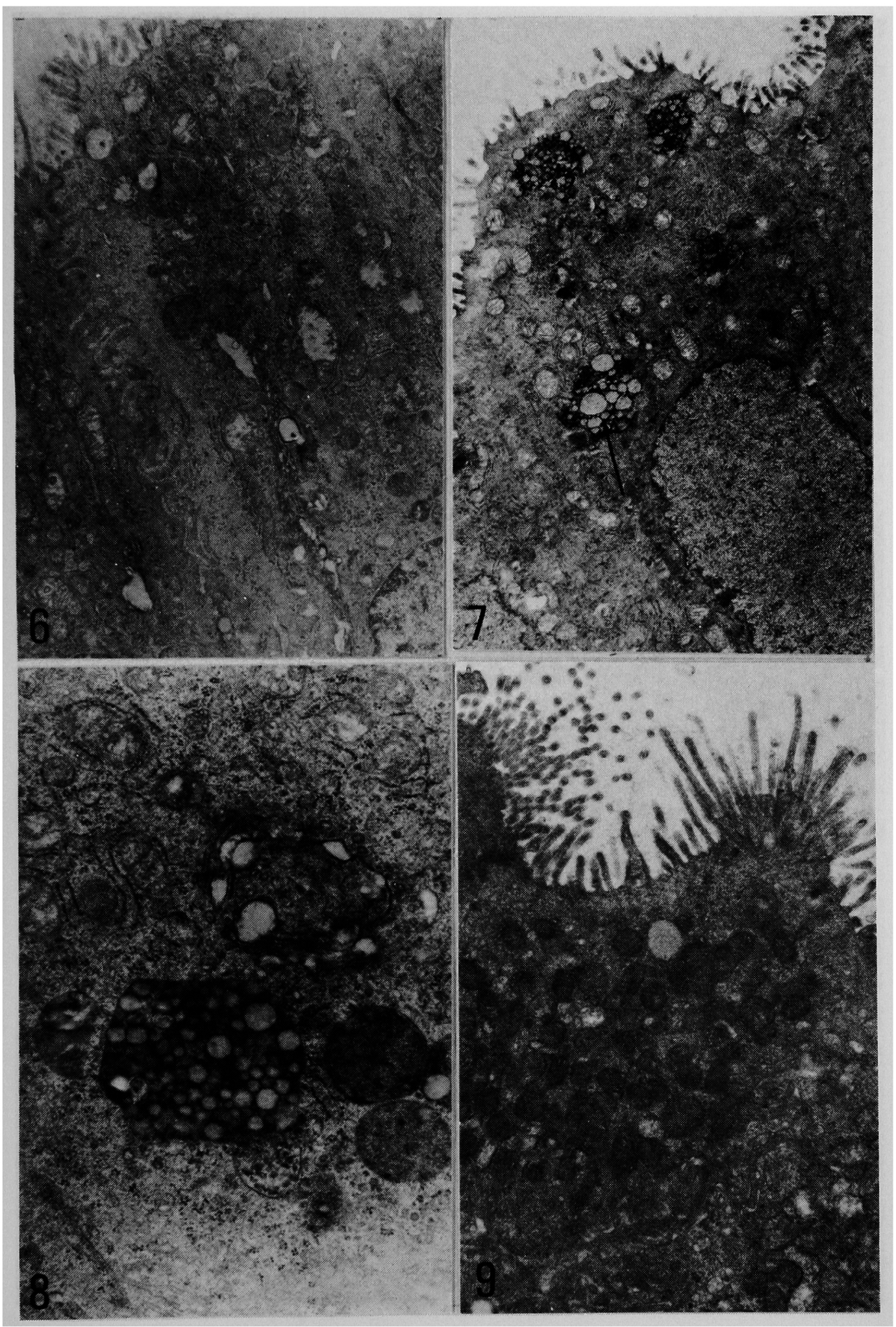




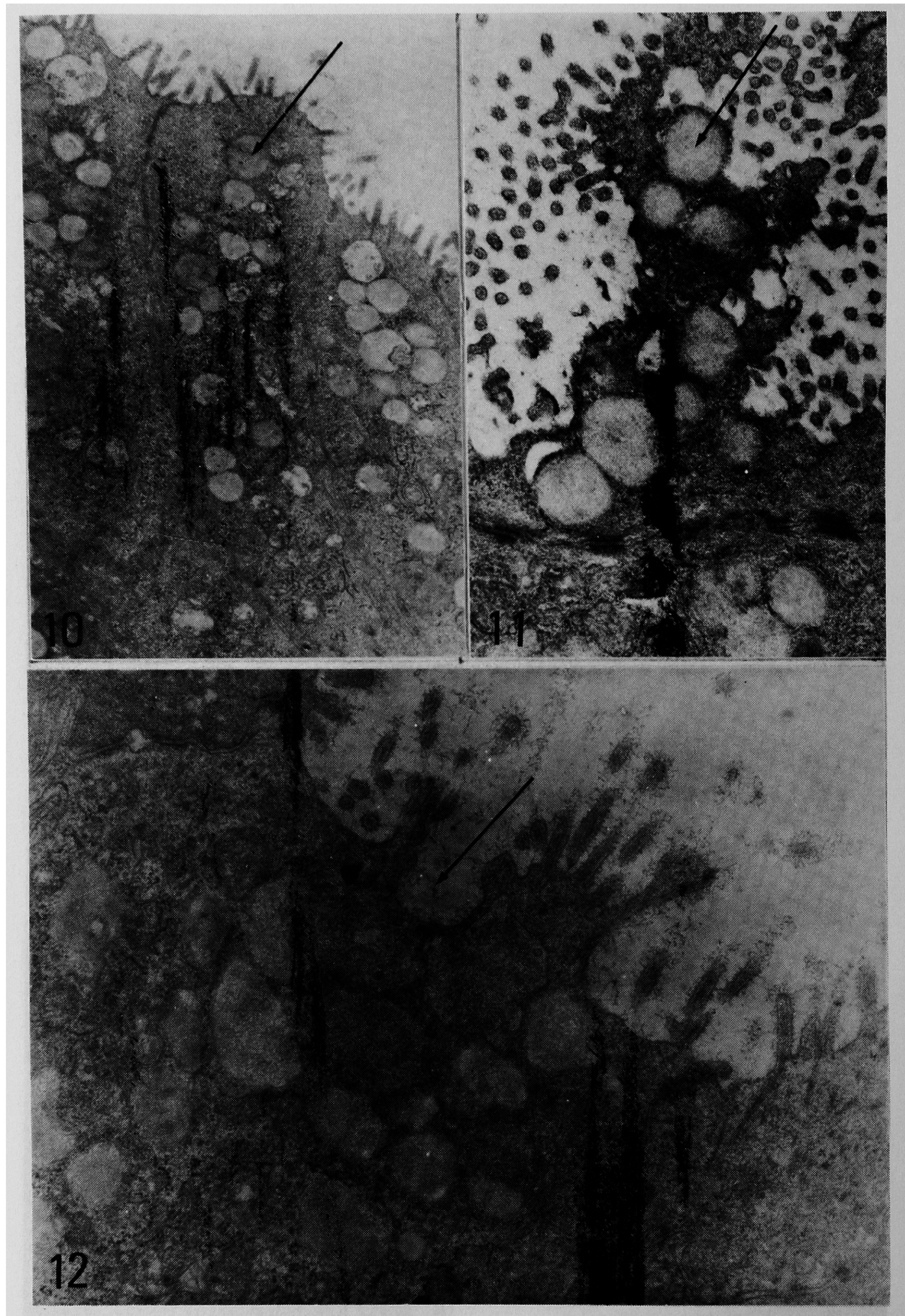




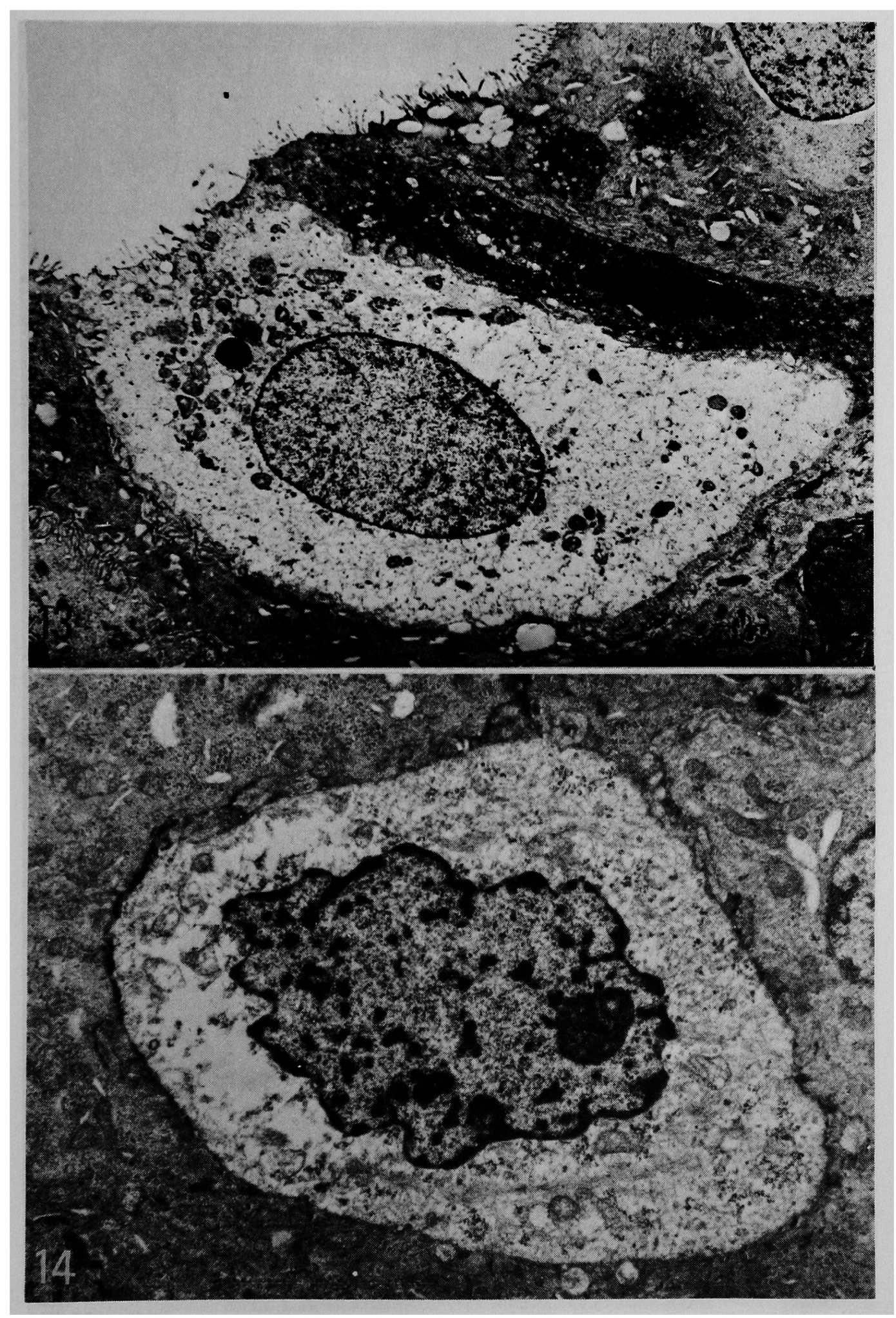




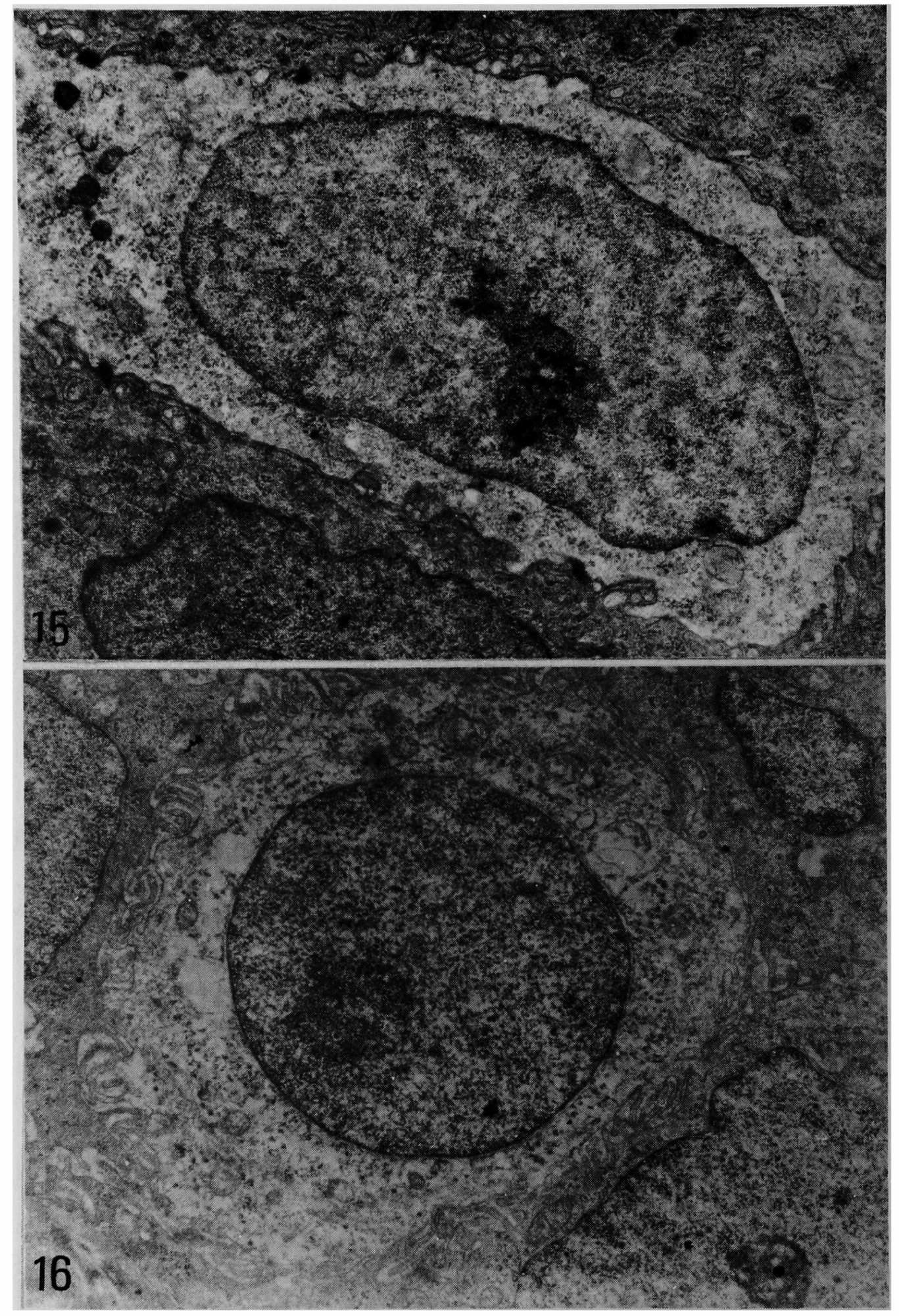




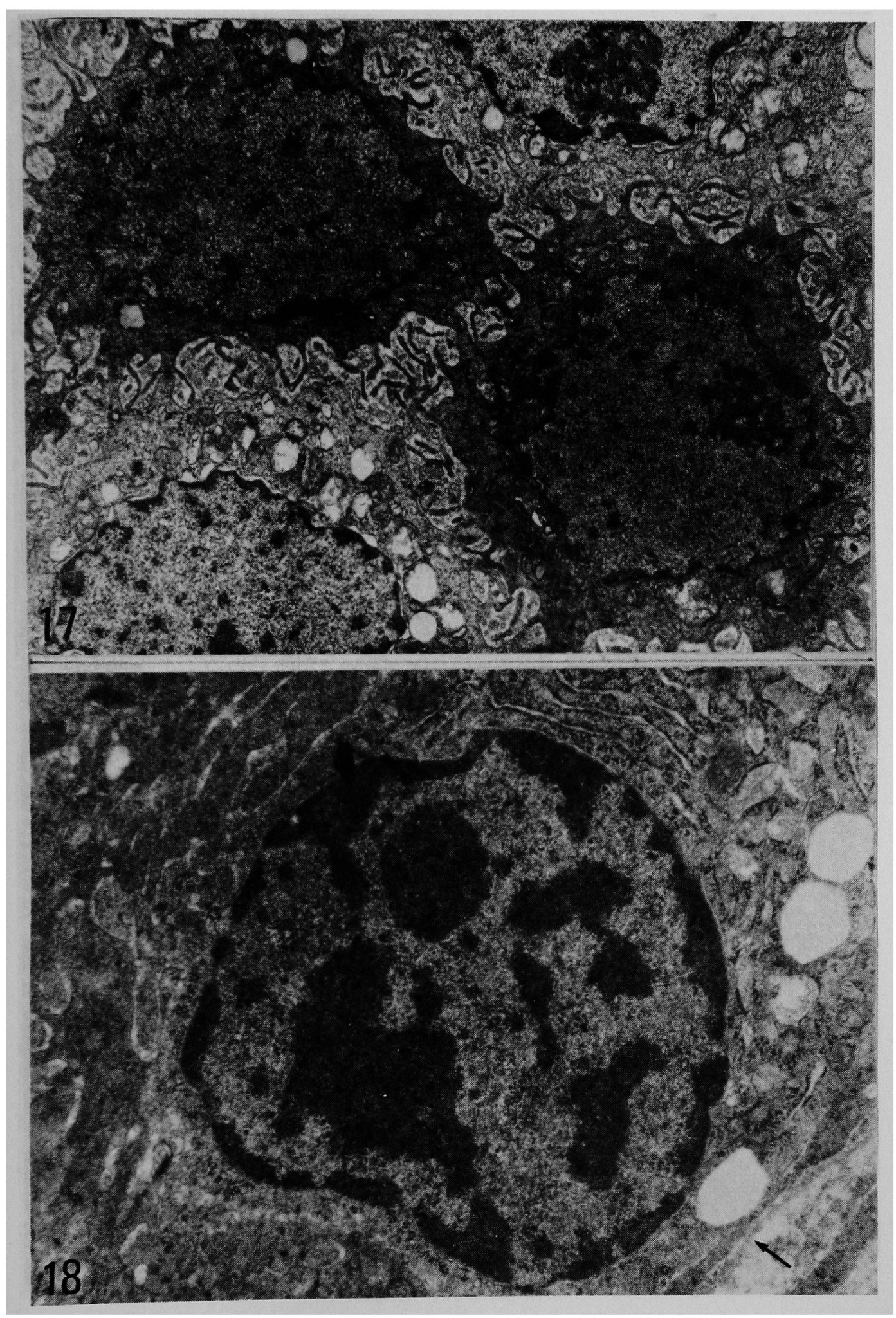




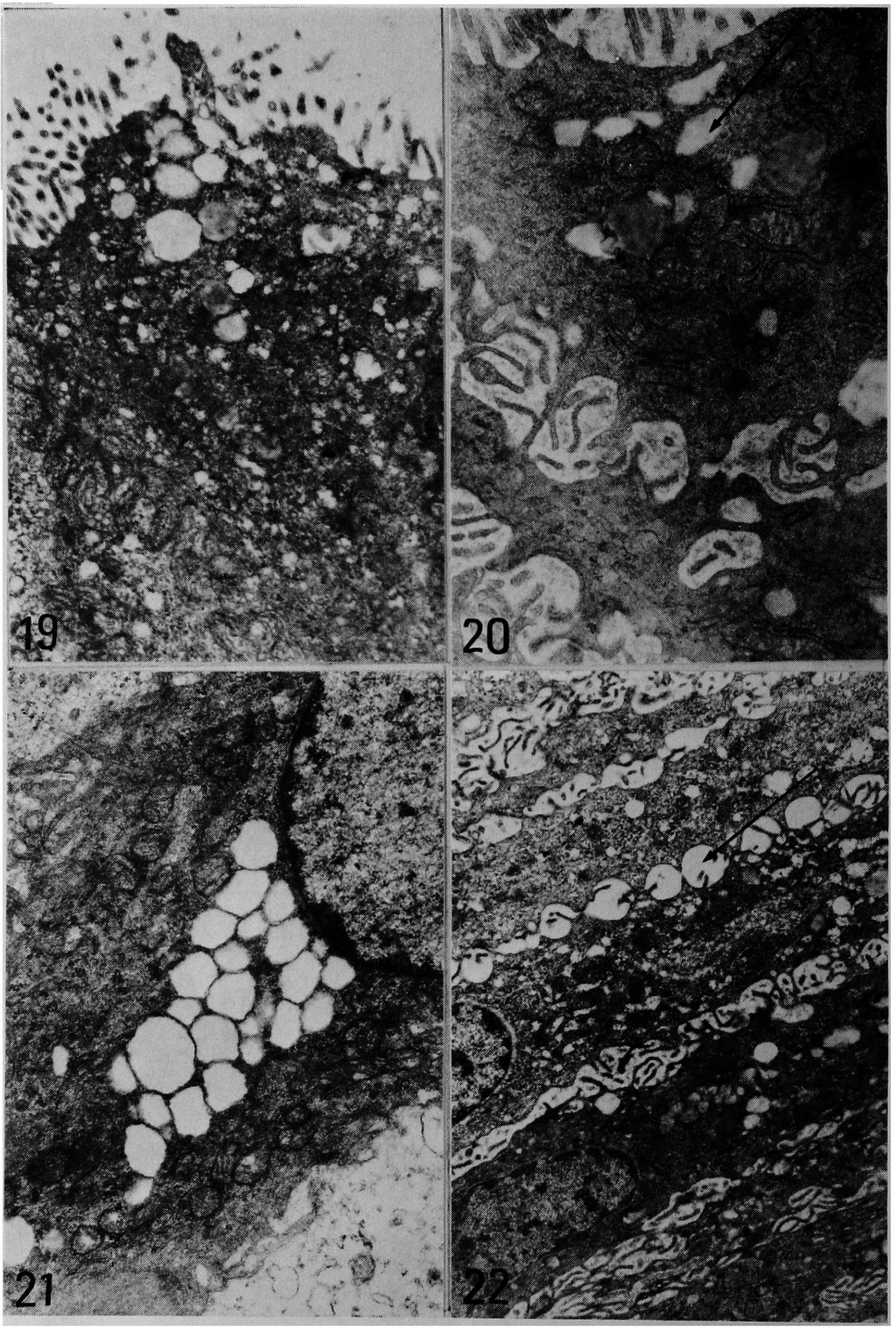




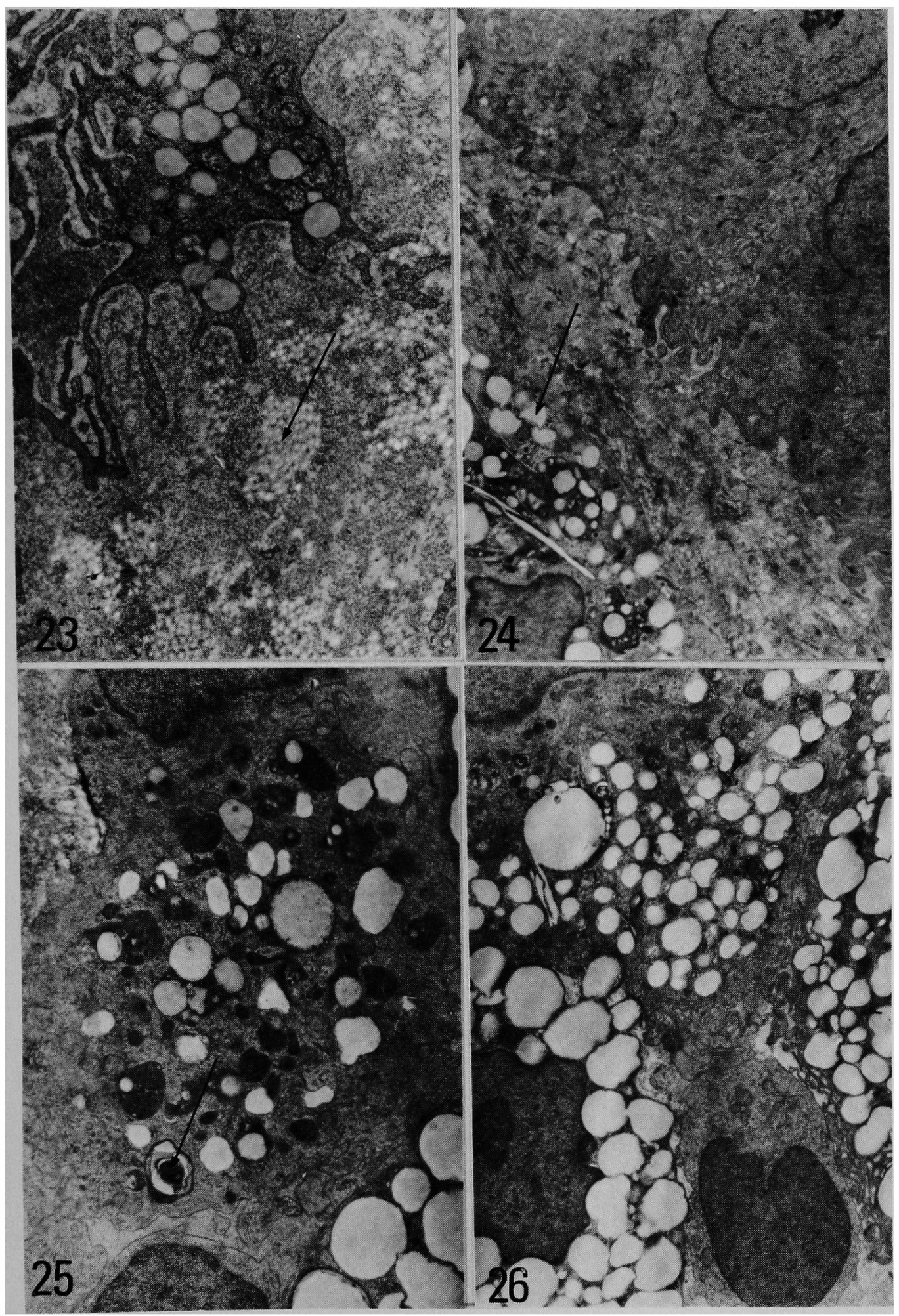

